\title{
PROFIL KEMAMPUAN PENALARAN MATEMATIS SISWA DITINJAU DARI GAYA BELAJAR V-A-K PADA MATERI BANGUN RUANG SISI DATAR
}

\author{
Siti Marwiyah ${ }^{1}$, Heni Pujiastuti², Sukirwan ${ }^{3}$ \\ 1,2,3 Universitas Sultan Ageng Tirtayasa, Jl.Raya Jakarta KM.4, Kota Serang, Indonesia \\ Email: sitimarwiyah244@gmail.com
}

\begin{abstract}
Students' ability to absorb, organize, and process the information on learning is not the same. This is due to differences in the characteristics of diverse learning styles. Differences in learning styles affect the learning process. Therefore, students must know in advance which learning style is appropriate for themselves. To make the most of it, students need to be recognized about the categories and characteristics of visual, auditory, or kinetic learning styles. This research aims to analyze and describe the profile of students' mathematical reasoning abilities in Flat Side Room Building materials reviewed from visual, auditory, and kinetic learning styles. This research is a descriptive study with a qualitative approach. The subject of his research was six-grade VIII-B students at SMP Negeri 3 Cilegon. The results of this study show that students with visual, auditory, and kinetic learning styles have different mathematical reasoning abilities on each indicator of mathematical reasoning abilities. Students with visual, auditory, and kinetic learning styles have good mathematical reasoning skills in drawing conclusions from statements. However, students with visual, auditory, and kinetic learning styles have weaknesses in compiling evidence.
\end{abstract}

Keywords: Auditory, kinesthetic, learning style, mathematical reasoning, visual

\begin{abstract}
ABSTRAK
Kemampuan siswa dalam menyerap, mengatur, dan mengolah informasi pada pembelajaran tidaklah sama. Hal ini terjadi karena perbedaan karakteristik gaya belajar yang beragam. Adanya perbedaan gaya belajar mempengaruhi proses pembelajaran yang diterapkan. Oleh karena itu, siswa harus mengetahui terlebih dahulu gaya belajar yang sesuai bagi dirinya sendiri. Untuk memaksimalkannya, siswa perlu dikenali mengenai kategori dan karakteristik gaya belajar visual, auditori, ataupun kinestetik. Penelitian ini bertujuan untuk menganalisis dan mendeskripsikan profil kemampuan penalaran matematis siswa pada materi Bangun Ruang Sisi Datar ditinjau dari gaya belajar visual, auditori, dan kinestetik. Penelitian ini merupakan penelitian deskriptif dengan pendekatan kualitatif. Subjek penelitiannya adalah enam siswa kelas VIII-B di SMP Negeri 3 Cilegon. Hasil dari penelitian ini menunjukkan bahwa siswa dengan gaya belajar visual, auditori, dan kinestetik memiliki kemampuan penalaran matematis yang berbeda pada setiap indikator kemampuan penalaran matematis. Siswa dengan gaya belajar visual, auditori, dan kinestetik memiliki kemampuan penalaran matematis yang baik dalam menarik kesimpulan dari pernyataan. Namun, siswa dengan gaya belajar visual, auditori, dan kinestetik memiliki kelemahan dalam menyusun bukti.
\end{abstract}

Kata kunci: Auditori, gaya belajar, kinestetik, penalaran matematis, visual

Dikirim: 30 Juli 2020; Diterima: 4 September 2020; Dipublikasikan: 30 September 2020

Cara sitasi: Marwiyah, S., Pujiastuti, H., \& Sukirwan. (2020). Profil kemampuan penalaran matematis siswa ditinjau dari gaya belajar v-a-k pada materi bangun ruang sisi datar. Teorema: Teori dan Riset Matematika, 5(2), 294-307. 


\section{PENDAHULUAN}

Salah satu tujuan pembelajaran matematika adalah melatih cara berpikir dan bernalar dalam menarik kesimpulan (Sumartini, 2015). Menurut Tinggi (Mikrayanti, 2016) matematika merupakan ilmu yang diperoleh melalui bernalar. Asnawati (2016) juga menyatakan bahwa matematika merupakan landasan dalam berpikir, bernalar, dan menarik kesimpulan sehingga kita terbantu dalam memahami, menguasai, dan memecahkan berbagai permasalahan. Sedangkan, Ruseffendi (Fadillah, 2016) menyatakan bahwa matematika timbul dari pikiran-pikiran yang berhubungan dengan ide, proses, dan penalaran. Berdasarkan definisi tersebut, matematika dan kemampuan penalaran matematis adalah dua hal yang berkaitan dan tidak dapat dipisahkan. Karena untuk memahami matematika diperlukan kemampuan penalaran matematis, kemampuan penalaran matematis dilatih melalui pembelajaran matematika (Agustina et al., 2018).

National Council of Teacher of Mathematics (NCTM, 2000) menetapkan lima standar proses yang harus dikuasi oleh siswa dalam pembelajaran matematika yaitu kemampuan pemecahan masalah matematis, kemampuan komunikasi matematis, kemampuan koneksi matematis, kemampuan penalaran matematis, dan kemampuan representasi matematis. Berdasarkan tujuan pembelajaran matematika dan standar proses yang harus dimiliki siswa di atas, kemampuan penalaran merupakan salah satu fokus dalam pembelajaran matematika dan merupakan kemampuan yang harus dimiliki siswa setelah mengikuti proses pembelajaran matematika.

Permendikbud Nomor 64 Tahun 2013 juga menyebutkan salah satu keterampilan yang harus dikuasai siswa yaitu menalar dalam ranah konkret dan ranah abstrak. Melalui pembelajaran matematika, siswa diharapkan mempunyai kemampuan penalaran matematis yang meliputi: (1) kemampuan mengajukan dugaan; (2) melakukan manipulasi matematika; (3) menarik kesimpulan, menyusun bukti, memberikan alasan/bukti terhadap kebenaran solusi; (4) menarik kesimpulan dari pernyataan; (5) memeriksa kesahihan suatu argument; dan (6) menemukan pola atau sifat dari gejala matematis untuk membuat generalisasi (Kemdikbud, 2013).

Menurut Shadiq (Dani et al., 2017) kemampuan penalaran adalah proses atau kegiatan berpikir yang berusaha menghubung-hubungkan fakta-fakta atau evidensi-evidensi yang diketahui (premis) menuju kepada pernyataan baru atau kesimpulan. Kemampuan penalaran matematis juga diartikan sebagai cara berpikir matematis siswa untuk menentukan kesimpulan, berdasarkan sumber yang relevan atau aturan yang sebelumnya telah dibuktikan kebenarannya (Lestari \& Prahmana, 2017). Kemampuan penalaran berlangsung ketika seseorang berpikir tentang suatu masalah atau menyelesaikan masalah (Sumarmo, 2013).

Ironisnya matematika merupakan mata pelajaran yang kurang disenangi oleh siswa, sehingga penguasaan siswa terhadap mata pelajaran dan kemampuan matematika termasuk penalaran matematis siswa menjadi sangat kurang (Hanifah et al., 2019). Terlihat dari hasil TIMSS tahun 2015, dimana rata-rata persentase jawaban benar siswa untuk kemampuan bernalarnya adalah 20 dibandingkan dengan 44 dari hasil internasional (Farida et al., 2018). Maka terlihat kemampuan penalaran matematis siswa masih belum optimal. Sejalan dengan itu Fajriyah \& Zanthy (2019) juga menyatakan masih banyak siswa yang belum memiliki kemampuan penalaran yang baik sehingga kemampuan penalaran yang dimiliki siswa masih belum optimal dan menjadi hambatan.

Setiap individu memiliki kemampuan penalaran yang berbeda-beda, hal tersebut dapat mempengaruhi hasil belajar matematika. Hal lain yang mempengaruhi hasil belajar yang perlu diperhatikan adalah perbedaan individu, salah satu adalah perbedaan gaya belajar. Gaya belajar merupakan salah satu cara dan strategi dalam belajar untuk mencapai suatu yang diharapkan yaitu hasil belajar yang baik. Utami \& Meliasari (2019) menyatakan bahwa kemampuan penalaran siswa untuk memahami dan menyerap pelajaran sudah pasti berbeda tingkatnya. Ada yang cepat, sedang dan ada pula yang sangat lambat. Hal tersebut dapat dipengaruhi oleh gaya belajar siswa. Informasi dapat disampaikan dengan cara yang berbeda sehingga dapat diserap oleh semua siswa.

Gaya belajar merupakan cara seseorang untuk menyerap, mengatur dan mengolah informasi atau pelajaran (Karim, 2014). Menurut DePorter \& Hernacky (2013) gaya belajar adalah 
kunci untuk mengembangkan kinerja dalam pekerjaan, sekolah, dan dalam situasi antar pribadi, dengan begitu gaya belajar akan mempengaruhi seseorang dalam menyerap dan mengolah informasi sehingga akan mempengaruhi prestasi yang dicapai. Lebih lanjut, DePorter \& Hernacky (2013) membagi gaya belajar menjadi tiga tipe yaitu visual, auditori, dan kinestetik. Siswa bertipe visual belajar melalui apa yang dilihat, siswa bertipe auditori belajar melalui apa yang didengar, dan siswa bertipe kinestetik belajar melalui gerak dan sentuhan. Walaupun siswa belajar menggunakan ketiga modalitas ini, kebanyakan orang lebih cenderung pada salah satu diantara ketiganya (Jaenudin et al., 2017).

Penelitian yang telah dilakukan oleh Ridwan (2017) menghasilkan bahwa kemampuan penalaran matematis siswa SMA pada materi fungsi komposisi dan fungsi invers untuk siswa dengan gaya belajar auditori meliputi indikator kemampuan memanipulasi, memberikan alasan atau bukti, memberikan argumen dan kesahihan jawaban baik dan menarik kesimpulannya cukup dibandingkan siswa yang memiliki gaya belajar visual dan kinestetik. Sedangkan hasil penelitian yang dilakukan oleh Haryono \& Tanujaya (2018) menyatakan bahwa kemampuan penalaran induktif mahasiswa UNIPA pada materi pola bilangan untuk mahasiswa dengan gaya belajar visual cenderung lebih baik dibandingkan dengan kemampuan penalaran induktif matematika mahasiswa yang belajar dengan gaya belajar auditori maupun yang belajar dengan gaya belajar kinestetik. Selain itu, mahasiswa UNIPA tidak mempunyai kemampuan untuk memeriksa kesahihan suatu argumen dan menemukan pola atau sifat dari gejala matematis untuk membuat generalisasi. Hasil ini menunjukkan adanya perbedaan kemampuan penalaran matematis siswa pada setiap tipe gaya belajar.

Beberapa penelitian yang telah dilakukan di atas, belum terdapat penelitian tentang kemampuan penalaran matematis siswa SMP pada materi bangun ruang sisi datar ditinjau dari gaya belajar. Bangun ruang sisi datar merupakan suatu bangun ruang yang membatasi bagian dalam dan luar berbentuk bidang datar yang dipelajari pada kelas VIII semester II. Sehingga, ini memotivasi peneliti untuk melakukan penelitian yang diharapkan dapat mendeskripsikan profil kemampuan penalaran matematis siswa kelas VIII SMP ditinjau dari gaya belajar visual, auditori, dan kinestetik pada materi bangun ruang sisi datar. Oleh karena ini, penelitian ini berjudul "Profil Kemampuan Penalaran Matematis Siswa ditinjau dari Gaya Belajar V-A-K pada Materi Bangun Ruang Sisi Datar".

\section{METODE PENELITIAN}

Jenis penelitian ini adalah penilitian deskriptif dengan pendekatan kualitatif. Penelitian ini dilakukan untuk mendeskripskan kemampuan penalaran matematis siswa SMP pada materi bangun ruang sisi datar ditinjau dari gaya belajar visual, auditori, dan kinestetik. Subjek penelitian ini adalah 6 siswa kelas VIII B di SMP Negeri 3 Cilegon. Instrumen utama yang digunakan dalam penelitian kualitatif adalah peneliti itu sendiri, namun selanjutnya setelah fokus penelitian menjadi jelas, maka dikembangkan instrumen sederhana yang diharapkan dapat melengkapi data hasil penelitian berupa instrumen tes penalaran matematis, angket gaya belajar, wawancara, dan dokumentasi.

Peneliti akan memberikan angket gaya belajar, tes kemampuan penalaran matematis materi bangun ruang sisi datar, serta wawancara mengenai gaya belajar dan bagaimana cara siswa mengerjakan tes kemampuan penalaran matematis yang dilakukan secara online karena sekolah mengikuti intruksi pemerintah untuk melaksanakan pembelajaran dari rumah dalam rangka pencegahan penyebaran wabah virus corona virus deases 2019 atau covid-19. Setelah didapat hasil angket penggolongan gaya belajar yang terbagi menjadi tiga golongan yaitu siswa visual, auditori, dan kinestetik. Kemudian, diambil subjek penelitian masing-masing 2 siswa dengan gaya belajar visual, 2 siswa dengan gaya belajar auditori, dan 2 siswa dengan gaya belajar kinestetik.

Teknik analisis data dalam penelitian ini sesuai dengan Miles dan Huberman (Sugiyono, 2010), yaitu data reduction, data display, dan conclusion drawing/verification yang dilakukan pada saat pengumpulan data berlangsung dan pada saat pengumpulan data selesai. 


\section{Angket Gaya Belajar}

Angket gaya belajar diberikan pada tanggal 5 Mei 2020 kepada siswa kelas VIII B SMP Negeri 3 Cilegon secara online menggunakan google form dengan google classroom sebagai kelas online-nya. Angket gaya belajar yang digunakan adalah angket yang dikembangkan oleh DePorter \& Hernacky (2013) yang terdiri dari 36 pernyataan. Adapun pedoman penskoran angket gaya belajar disajikan dalam Tabel 1 .

Tabel 1. Pedoman penskoran angket gaya belajar

\begin{tabular}{ccc}
\hline No & Jawaban & Skor \\
\hline 1 & Sering & 2 \\
2 & Kadang-kadang & 1 \\
3 & Tidak pernah & 0 \\
\hline
\end{tabular}

Selanjutnya data hasil angket gaya belajar dianalisis berdasarkan pedoman penskoran, kemudian dihitung jumlah skor tiap butir pernyataan sesuai dengan aspek yang diamati. Kemudian skor yang lebih besar menunjukkan golongan gaya belajarnya.

2. Tes Kemampuan Penalaran Matematis

Tes kemampuan penalaran matematis diberikan pada tanggal 5 Mei 2020 kepada kelas VIII B SMP Negeri 3 Cilegon secara online dengan google classroom sebagai kelas online-nya. Indikator kemampuan penalaran matematis yang digunakan dalam penelitian ini berdasarkan Peraturan Dirjen Dikdasmen Depdiknas Nomor 506/C/Kep/PP/2004 (Kemdikbud, 2013) yaitu:

a. Mengajukan dugaan

b. Melakukan manipulasi matematika

c. Menyusun bukti, memberikan alasan atau bukti terhadap kebenaran solusi

d. Menarik kesimpulan dari pernyataan

e. Memeriksa kesahihan suatu argumen

f. Menemukan pola atau sifat dari gejala matematis untuk membuat generalisasi.

Adapun pedoman penskoran kemampuan penalaran matematis disajikan pada Tabel 2.

Tabel 2. Pedoman penskoran tes kemampuan penalaran matematis

\begin{tabular}{lc}
\hline \multicolumn{1}{c}{ Respon } & Skor \\
\hline Tidak ada jawaban/ menjawab tidak sesuai dengan pertanyaan/ tidak ada & 0 \\
yang benar & 1 \\
Hanya menjawab sebagian yang benar & 2 \\
$\begin{array}{l}\text { Menjawab hampir semua benar dari pertanyaan } \\
\text { Menjawab dengan mengikuti keserupaan data, dan menarik kesimpulan serta }\end{array}$ & \\
dijawab dengan lengkap/jelas dan benar & 3 \\
\hline
\end{tabular}

3. Wawancara

Wawancara dilakukan pada tanggal 20 sampai 22 Mei 2020 secara online melalui telepon whatsapp. Hasil wawancara kemudian dianalisis secara deskriptif dengan harapan dapat membantu peneliti untuk mengetahui lebih dalam mengenai gaya belajar dan cara siswa dalam menyelesaikan tes kemampuan penalaran matematis.

\section{HASIL DAN PEMBAHASAN}

Angket gaya belajar diberikan untuk mengetahui gaya belajar apa yang dimiliki oleh siswa. Selanjutnya, siswa dikelompokkan berdasarkan gaya belajarnya menjadi tiga yaitu siswa visual, siswa auditori, dan siswa kinestetik. Angket ini diberikan kepada 30 siswa kelas VIII B di SMP Negeri 3 Cilegon, namun hanya 21 siswa yang mengisi angket gaya belajar dikarenakan siswa lebih terfokus pada pengerjaan soal tes kemampuan penalaran matematis, sehingga lupa mengisi angket gaya belajar sampai batas waktu yang ditentukan. Adapun hasil pengukuran gaya belajar ditampilkan pada Gambar 1. 


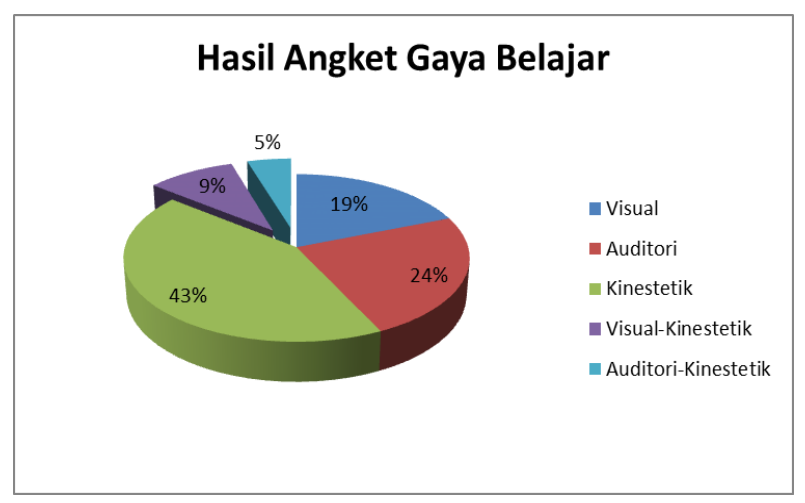

Gambar 1. Persentase hasil angket gaya belajar

Berdasarkan Gambar 1, dari 21 siswa kelas VIII B yang mengisi angket penggolongan gaya belajar terdapat 4 siswa tergolong gaya belajar visual $(19 \%), 5$ siswa tergolong gaya belajar auditori (24\%), 9 siswa tergolong gaya belajar kinestetik (43\%), 2 siswa tergolong gaya belajar visualkinestetik (9\%), dan 1 siswa tergolong gaya belajar auditoril-kinestetik (5\%). Namun, pada penelitian ini hanya tiga gaya belajar saja yang akan menjadi fokus penelitian yaitu: visual, auditori, dan kinestetik. Maka siswa yang tergolong gaya belajar visual-kinestetik dan auditori-kinestetik tidak menjadi subjek penelitian.

Dari 4 siswa dengan gaya belajar visual, 5 siswa dengan gaya belajar auditori, 9 siswa dengan gaya belajar kinestetik tersebut memiliki nilai tes penalaran matematis yang berbeda-beda. Sehingga untuk lebih memudahkan membaca hasil penelitian, peneliti menentukan subjek penelitian untuk diteliti lebih jauh lagi mengenai kemampuan penalaran matematis siswa SMP Negeri 3 Cilegon kelas VIII B pada materi Bangun Ruang Sisi Datar. Subjek penelitian dipilih secara pusposive sampling masing-masing perwakilan golongan gaya belajar dengan kriteria (1) memiliki gaya belajar visual, auditori, atau kinestetik berdasarkan hasil angket gaya belajar; (2) memiliki kemampuan penalaran matematis tertinggi; (3) dapat mengemukakan ide atau pendapatnya secara lengkap dan jelas. Berdasarkan kriteria tersebut, diperoleh 6 siswa yang terdiri dari 2 siswa visual, 2 siswa auditori, dan 2 siswa kinestetik.

Selanjutnya untuk melihat sejauh mana kemampuan penalaran matematis siswa, maka jawaban masing-masing siswa visual pertama (SV1), jawaban siswa visual kedua (SV2), jawaban siswa auditori pertama (SA1), jawaban siswa auditori kedua (SA2), jawaban siswa kinestetik pertama (SK1), jawaban siswa kinestetik kedua (SK2) akan dibahas berdasarkan hasil tes yang telah disesuaikan dengan indikator.

Jawaban soal nomor 1 untuk indikator mengajukan dugaan berdasarkan gaya belajar siswa ditampilkan pada Gambar 2, Gambar 3, dan Gambar 4.

1. - lya, karena setiap sisi kubus memiliki ukuran
yang sama.
- Tidak, karena balok memiliki panjang dan lebar
yang berbeda.

Gambar 2. Jawaban soal nomor 1 SV1

1. - lya, karena Af dan BG merupakan diagonal
bidang. Tetapi, panjangnya berbeda dengan
EC dan HB karena berbeda diagonal.
- lya, karena AF dan BG merupakan diagonal
bidang. Tetapi, pañjangnya berbeda dengan
EC dan HB karena berbeda diagonal.

Gambar 3. Jawaban soal nomor 1 SK1 


\begin{tabular}{l} 
1. - Sama, karena kubus memiliki dua belas \\
diagonal yang sama dan empat diagonal \\
\hline ruang yang sama. Ec dan HB termasuk \\
diagonal ruang, dan Af dan BE merupakan \\
\hline diagonal bidang. \\
\hline - Sama, karena balok juga meniliki empat \\
\hline diagonal dan dua belas diugonal bidang \\
\hline yang memilika ukuran yang sama, EC \\
\hline dan HB termasuk diagonal ruang, dan \\
\hline Af dan BE termasuk dragonal bidang.
\end{tabular}

Gambar 4. Jawaban soal nomor $1 \mathrm{SA} 1$

Sesuai dengan yang dapat dilihat pada Gambar 2, siswa visual mampu mengajukan dugaan dengan baik, karena dapat memberikan alasan yang tepat berdasarkan informasi pada soal yaitu disediakan gambar yang memuat diagonal ruang EC dan HB pada kubus yang sama panjang, dan berdasarkan pengetahuan bahwa kubus memiliki ukuran sisi yang sama, sehingga panjang diagonal bidang AF dan BG pada kubus juga sama panjang. Sedangkan, pada balok meskipun memiliki diagonal ruang EC dan HB sama panjang, namun siswa visual mengetahui bahwa balok memiliki ukuran sisi yang berbeda sehingga panjang diagonal bidang AF dan BG pada balok berbeda. Hal ini sesuai dengan penelitian yang dilakukan oleh Haryono \& Tanujaya (2018) bahwa siswa visual memiliki kemampuan mengajukan dugaan yang baik, dan juga sesuai dengan karakteristik menurut DePorter \& Hernacky (2013) bahwa siswa visual teliti terhadap detail dan melakukan pekerjaan dengan baik jika melibatkan visualisasi.

Sesuai dengan yang dapat dilihat pada Gambar 3, siswa kinestetik kurang mampu mengajukan dugaan dengan benar, karena siswa kinestetik memberikan alasan yang kurang tepat berdasarkan pada permasalahan yaitu disediakan gambar yang memuat diagonal ruang EC dan HB pada kubus yang sama panjang, diagonal bidang AF dan BG keduanya merupakan diagonal bidang sehingga memiliki panjang yang sama. Begitu juga diagonal pada balok, siswa kinestetik menduga bahwa diagonal bidang AF dan BG pada balok memiliki panjang yang sama karena keduanya merupakan diagonal bidang, tidak memperhatikan ukuran sisi/bidang balok pada gambar.

Sesuai dengan yang dapat dilihat pada Gambar 4, siswa auditori kurang mampu mengajukan dugaan dengan benar. Siswa auditori dapat memberikan alasan yang tepat berdasarkan pada permasalahan yaitu disediakan gambar yang memuat diagonal ruang EC dan HB pada kubus yang sama panjang, dan berdasarkan pengetahuan bahwa kubus memiliki 12 diagonal bidang yang sama panjang sehingga panjang diagonal bidang AF dan BG pada kubus juga memiliki panjang yang sama. Namun, pada balok karena mamiliki diagonal ruang EC dan HB sama panjang, dan kesalahan pemahaman bahwa balok juga memiliki 12 diagonal bidang yang sama panjang, sehingga siswa auditori menganggap diagonal bidang AF dan BG pada balok juga sama panjang, padahal pada gambar jelas terlihat sisi bidang diagonal AF dan BG memiliki ukuran yang berbeda.

Jawaban soal nomor 2 untuk indikator melakukan manipulasi matematika berdasarkan gaya belajar siswa ditampilkan pada Gambar 5, Gambar 6, dan Gambar 7.

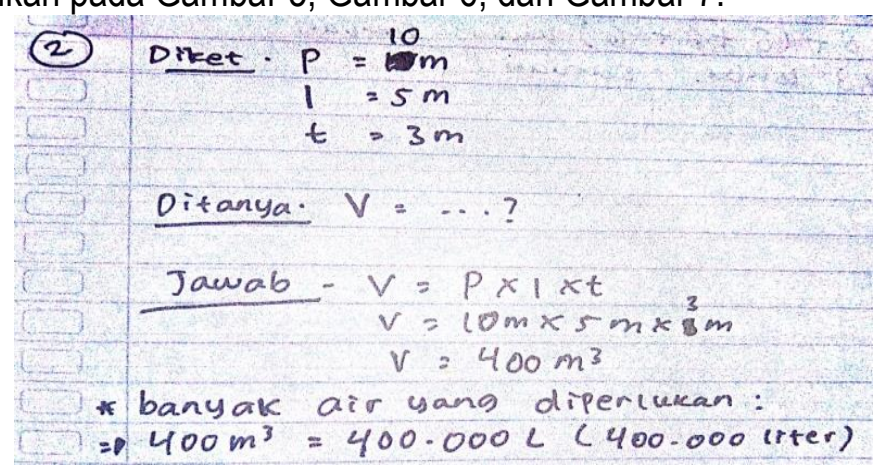

Gambar 5. Jawaban soal nomor 2 SV2 


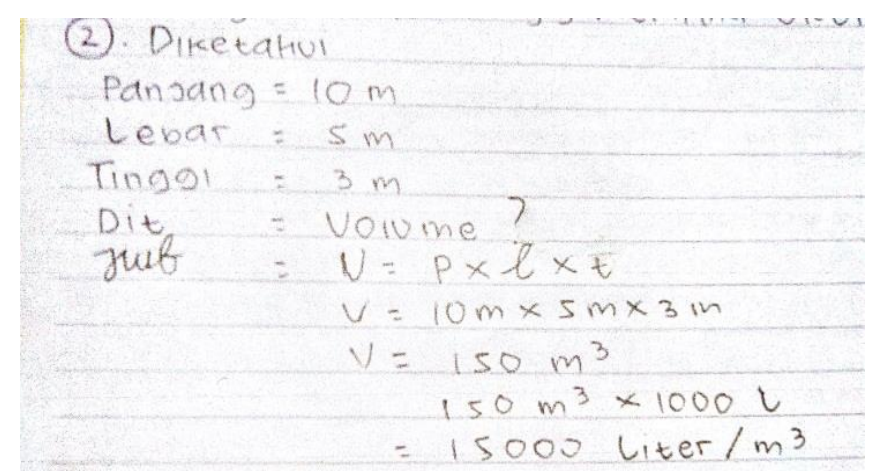

Gambar 6. Jawaban soal nomor 2 SA2

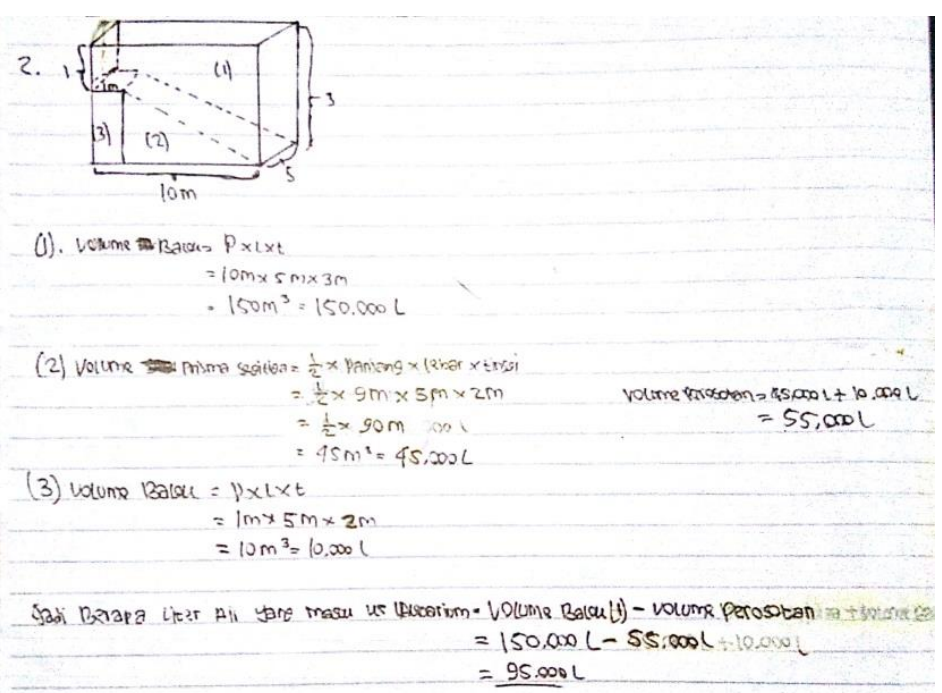

Gambar 7. Jawaban soal nomor 2 SK1

Sesuai dengan yang dapat dilihat pada Gambar 5, siswa visual kurang mampu melakukan manipulasi matematika, karena siswa visual tidak mampu menemukan beberapa rumus perhitungan matematika dan menggabungkannya menjadi rumus perhitungan yang dibutuhkan. Siswa visual hanya dapat menemukan nilai $p$, I dan $t$ untuk balok (1) tetapi dalam menghitunga volume balok (1) masih melakkan kesalahan dalam operasi hitungnya. Siswa visual tidak dapat menemukan volume prisma (2) dan balok (3), sehingga siswa visual tidak mampu melakukan manipulasi matematika untuk menghitung volume air yang dibutuhkan untuk mengisi kolam renang.

Sesuai dengan yang dapat dilihat pada Gambar 6, siswa auditori kurang mampu melakukan manipulasi matematika, karena siswa auditori tidak mampu menemukan beberapa rumus perhitungan matematika dan menggabungkannya menjadi rumus perhitungan yang dibutuhkan. Siswa auditori hanya mampu menemukan nilai $p, I, t$ untuk balok (1), kemudian menghitung volume dari balok (1) tersebut. Namun, tanpa mencari volume prisma (2) dan balok (3), siswa auditori langsung mengubah hasil volume balok besar (bangun 1) kedalam satuan liter. Sehingga, siswa auditori tidak mampu melakukan manpulasi matematika untuk menghitung volume air yang dibutuhkan untuk mengisi kolam renang.

Sesuai dengan yang dapat dilihat pada Gambar 7, siswa kinestetik mampu melakukan manipulasi matematika dengan tepat, karena siswa kinestetik mampu menemukan beberapa rumus perhitungan matematika dan menggabungkannya menjadi rumus perhitungan yang dibutuhkan. Siswa kinestetik mampu menemukan volume dari balok (1), volume prisma (2), dan balok (3). Kemudian, siswa kinestetik melakukan rekayasa matematika dengan menggabungkan volume prisma (2) dengan balok (3) dan disebut volume perosotan. Setelah itu, untuk menemukan volume air yang dibutuhkan untuk mengisi kolam renang, siswa kinestetik mengurangkan volume balok (1) dengan volume perosotan hasil rekayasa matematika dari volume prisma (2) dan balok (3). Karena 
hal itu, dapat diketahui siswa kinestetik mampu melakukan manpulasi matematika untuk menghitung volume air yang dibutuhkan untuk mengisi kolam renang. Hal ini sesuai dengan karakteristik menurut DePorter \& Hernacky (2013) bahwa siswa dengan gaya belajar kinestetik belajar melalui memanipulasi dan praktik.

Jawaban soal nomor 3 untuk indikator menyusun bukti, memberikan alasan atau bukti terhadap kebenaran solusi berdasarkan gaya belajar siswa ditampilkan pada Gambar 8, Gambar 9, dan Gambar 10.

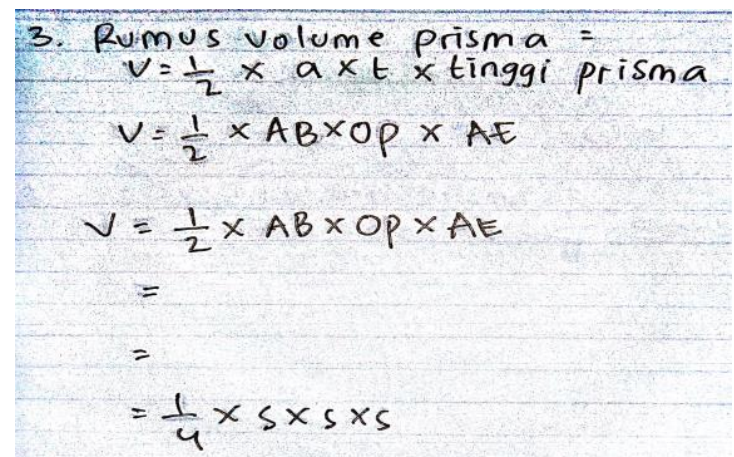

Gambar 8. Jawaban soal nomor 3 SV1

3. Benar, karena terdapat 4 prisma segitiga
pada setiap bidang dan ABO.EFT adalah
potong prisma I dari 4 prisma segitiga
$=1 / 4$ volume.

Gambar 9. Jawaban soal nomor 3 SA1

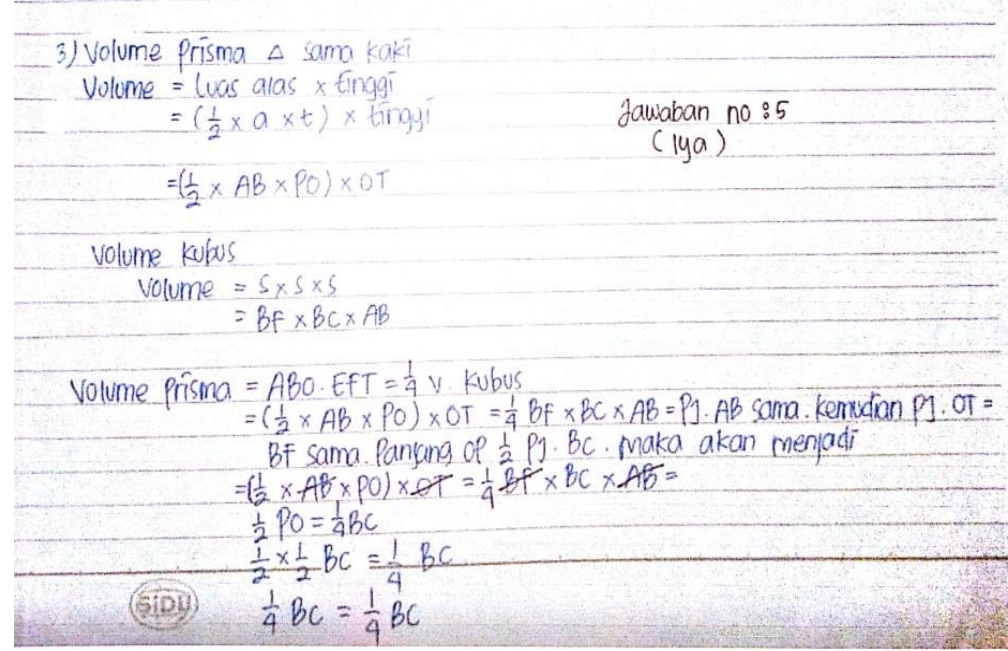

Gambar 10. Jawaban soal nomor 3 SK2

Sesuai dengan yang dapat dilihat pada Gambar 8, siswa visual kurang mampu menarik kesimpulan, menyusun bukti, memberikan alasan atau bukti terhadap kebenaran solusi, karena siswa visual hanya mampu mengemukakan rumus volume prisma yaitu $(1 / 2 \times a \times t) \times$ tinggi prisma, tetapi tidak mampu melakukan penyelidikan untuk membuktikan kebenaran solusi bahwa volume prisma ABO.EFT = $1 / 4$ volume kubus ABCD.EFGH.

Sesuai dengan yang dapat dilihat pada Gambar 9, siswa auditori kurang mampu menarik kesimpulan, menyusun bukti, memberikan alasan atau bukti terhadap kebenaran solusi, karena siswa auditori hanya memberikan alasan bahwa solusi yang dikemukakan pada soal adalah benar, namun siswa auditori tidak mampu melakukan penyelidikan untuk membuktikan kebenaran solusi bahwa volume prisma $A B O . E F T=1 / 4$ volume kubus ABCD.EFGH.

Sesuai dengan yang dapat dilihat pada Gambar 10, siswa kinestetik juga kurang mampu 
menarik kesimpulan, menyusun bukti, memberikan alasan atau bukti terhadap kebenaran solusi. Siswa kinestetik mampu mengemukakan rumus prisma yaitu $(1 / 2 \times a \times t) \times$ tinggi prisma dan mengubah simbolnya menjadi sesuai dengan simbol kubus yang tertera pada soal yaitu $(1 / 2 \times A B \times$ PO) $\times$ OT, kemudian siswa kinestetik juga mampu mengemukakan rumus volume kubus yaitu $s \times s$ $\times s$ dan mengubahnya menjadi $B F \times B C \times A B$. Namun, siswa kinestetik masih melakukan kesalahan dalam melakukan penyelidikan untuk untuk membuktikan kebenaran solusi bahwa volume prisma $A B O . E F T=1 / 4$ volume kubus $A B C D$.EFGH.

Jawaban soal nomor 4 untuk indikator menarik kesimpulan dari pernyataan berdasarkan gaya belajar siswa ditampilkan pada Gambar 11, Gambar 12, dan Gambar 13.

\begin{tabular}{l|c|c|c|c|c|}
\hline 4. & Bentuk & limas & limas & limas & Irmas \\
\hline Limas & Segitiga & Segiempat & segilima & segi-n \\
\hline Srsi & $4=(3)+1$ & $5=(4)+1$ & $6=(5)+1$ & $n+1$ \\
\hline Rusuk & $6=(3) \times 2$ & $8=(4) \times 2$ & $10=(5) \times 2$ & $n \times 2$ \\
Trifik Sudut & $4=(3)+1$ & $5=(4)+1$ & $6=(5)+1$ & $n+1$ \\
\hline
\end{tabular}

Gambar 11. Jawaban soal nomor 4 SV1

4. - Sri limas segi-n = memiliki $n$ Sisi segitiga
sebagai sisi tegaknga dan sebuah segi $-n$
sebagai alasnya.
- Rusuk Irmas segi $-n=2 \times n$ rusuk
- Tisik sudat limas segi-n $=n+1$ fitik Sudut

Gambar 12. Jawaban soal nomor 4 SA1

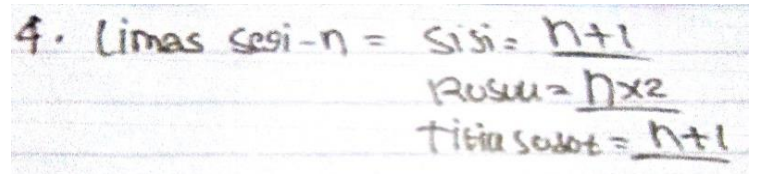

Gambar 13. Jawaban soal nomor 4 SK1

Sesuai dengan yang dapat dilihat pada Gambar 11, siswa visual mampu menarik kesimpulan dari pernyataan dengan tepat, karena siswa visual mampu menarik intisari dari keterkaitan pernyataan satu dengan lainnya. Siswa visual mengaitkan berdasarkan pernyataan yang terdapat pada soal yaitu jumlah sisi, rusuk, dan titik sudut pada limas segitiga, limas segiempat, dan limas segilima. Kemudian, menarik intisari dari pernyataan-pernyataan tersebut menjadi jumlah sisi, rusuk, dan titik sudut untuk limas segi-n dalam bentuk tabel yaitu sisinya $n+1$, rusuknya $2 x n$, dan titik sudutnya $n+1$. Hal ini, sesuai dengan karakteristik menurut DePorter \& Hernacky (2013) bahwa siswa dengan gaya belajar visual mementingkan penampilan, rapi dan teratur.

Sesuai dengan yang dapat dilihat pada Gambar 12, siswa auditori mampu menarik kesimpulan dari pernyataan, karena siswa auditori mampu menarik intisari dari keterkaitan pernyataan satu dengan lainnya. Berdasarkan pernyataan mengenai jumlah sisi, rusuk, dan titik sudut pada limas segitiga, segiempat, dan segilima siswa auditori mampu menarik intisari bahwa jumlah sisi untuk limas segi-n adalah $n$ sisi segitiga dan 1 sisi alas, namun siswa auditori tidak menuliskan $n+1$. Untuk jumlah rusuk dan titik sudut limas segi-n, siswa auditori menarik kesimpulan dengan benar yaitu rusuknya $2 x n$ dan titik sudutnya $n+1$. Siswa auditori juga hanya menuliskan kesimpulannya, tidak menuliskan secara lengkap keterkaitan dari pernyataan satu dengan lainnya. Hal ini, sesuai dengan karakteristik menurut DePorter \& Hernacky (2013) bahwa siswa dengan gaya belajar auditori merasa kesulitan untuk menulis tetapi hebat dalam berbicara.

Sesuai dengan yang dapat dilihat pada Gambar 13, siswa kinestetik mampu menarik kesimpulan dari pernyataan, karena siswa auditori mampu menarik intisari dari keterkaitan pernyataan satu dengan lainnya. Berdasarkan pernyataan mengenai jumlah sisi, rusuk, dan titik 
sudut pada limas segitiga, segiempat, dan segilima siswa visual mampu menarik intisari bahwa jumlah sisi pada limas segi-n adalah $n+1$, jumlah rusuk pada limas segi-n adalah $2 \times n$, dan jumlah titik sudut pada limas segi-n adalah $n+1$. Namun, siswa auditori hanya menuliskan kesimpulannya, tidak menuliskan secara lengkap keterkaitan dari pernyataan satu dengan lainnya.

Jawaban soal nomor 5 untuk indikator memeriksa kesahihan suatu argumen berdasarkan gaya belajar siswa ditampilkan pada Gambar 14, Gambar 15, dan Gambar 16.

\begin{aligned} & 5. $t=v:(1 / 3 \times$ luas alas $) \\ &$\hline$t=120:(1 / 8 \times$ go 30$) \\ & t=120: 30 \\ & t=4 \\ & t=v:(1 / 3 \times$ luas alas $) \\ & t=120:(1 / 8 \times 18660) \\ & t=120=60 \\ & t=2 \\ & y_{a}\end{aligned}$

Gambar 14. Jawaban soal nomor 5 SV1

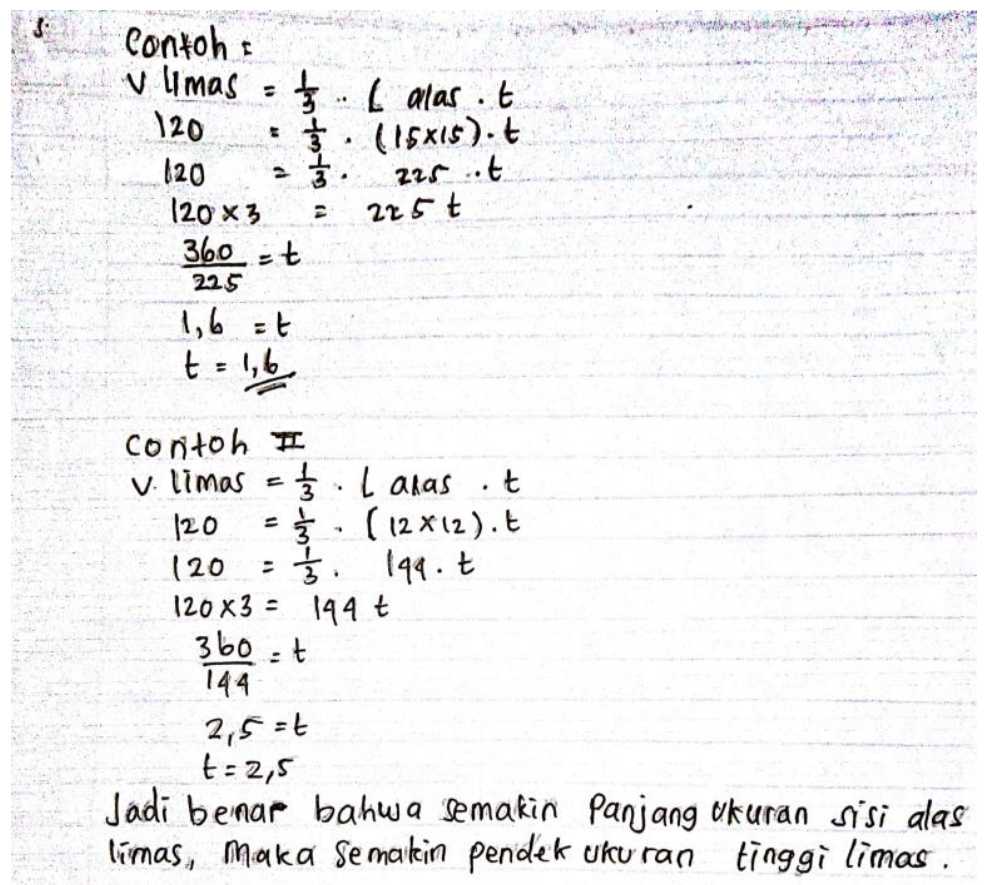

Gambar 15. Jawaban soal nomor 5 SA1

5. Iya, Jika sisi alas semakin lebar ataw banyak,
maka tingainya akan semakin rendah.

Gambar 16. Jawaban soal nomor 5 SK1

Sesuai dengan yang dapat dilihat pada Gambar 14, siswa visual kurang mampu memeriksa kesahihan argumen, karena siswa visual melakukan kesalahan dalam menyelidiki kebenaran dari suatu pernyataan yang ada dengan berpedoman pada hasil matematika yang diketahui. Siswa visual melakukan langkah awal yang benar berupa memberikan pemisalan pada panjang sisi alas untuk dua limas segiempat, sedangkan kedua limas telah diketahui pada soal. Namun, siswa visual melakukan kesalahan dalam mencari ukuran tinggi limasnya, rumus yang digunakan adalah $\mathrm{t}=\mathrm{V} /$ $((\mathrm{s}) / 3)$, yang seharusnya adalah $\mathrm{t}=\mathrm{V} /((\mathrm{s} \times \mathrm{s}) / 3)$. Sehingga, siswa kurang mampu memeriksa kesahihan argumen dikrenakan tidak mampu melakukan penyelidikan dengan benar, meskipun 
kesimpulan yang diambil siswa visual bahwa kesahihan argumen semakin panjang sisi alas maka semakin pendek tinggi limasnya adalah benar.

Sesuai dengan yang dapat dilihat pada Gambar 15, siswa auditori mampu memeriksa kesahihan suatu argumen dengan tepat, karena siswa auditori mampu menyelidiki kebenaran dari suatu pernyataan yang ada dengan berpedoman pada hasil matematika yang diketahui. Siswa auditori menyelidiki kebenaran dari suatu pernyataan dengan cara memisalkan panjang sisi alas pada dua limas segiempat, dimana panjang sisi limas pertama lebih panjang dari sisi limas kedua, kemudian mencari tinggi limasnya dikarenakan volume limas telah diketahui pada soal. Dengan rumus volume limas $V=1 / 3 \times s \times s \times T$ siswa auditori mampu menemukan tinggi limas pertama dan kedua, kemudian berpedoman pada hasil tinggi kedua limas, kesahihan argumen bahwa semakin panjang sisi alas maka semakin pendek tinggi limasnya terbukti.

Sesuai dengan yang dapat dilihat pada Gambar 16, siswa kinestetik kurang mampu memeriksa kesahihan suatu argumen dengan tepat, karena siswa kinestetik tidak mampu menyelidiki kebenaran dari suatu pernyataan yang ada dengan berpedoman pada hasil matematika yang diketahui. Siswa kinestetik hanya memberikan alasan bahwa argumen bahwa semakin panjang sisi alas maka semakin pendek tinggi limasnya adalah benar. Namun, siswa auditori tidak mampu melakukan penyelidikan untuk mendapatkan hasil matematika, dimana penyelidikan yang seharusnya dilakukan yaitu memisalkan panjang sisi alas pada dua limas segiempat, kemudian mencari masing-masing tinggi limasnya karena volume limas telah diketahui. Hasil perhitungan itu kemudian dijadikan sebagai pedoman terbuktinya kesahihan suatu argumen.

Jawaban soal nomor 6 untuk indikator menemukan pola atau sifat dari gejala matematis untuk membuat generalisasi berdasarkan gaya belajar ditampilkan pada Gambar 17, Gambar 18, dan Gambar 19.

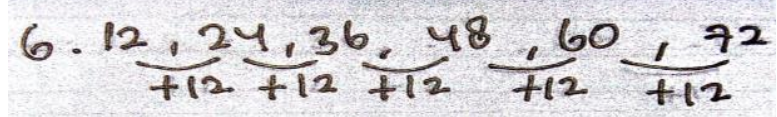

Gambar 17. Jawaban soal nomor 6 SV1

6

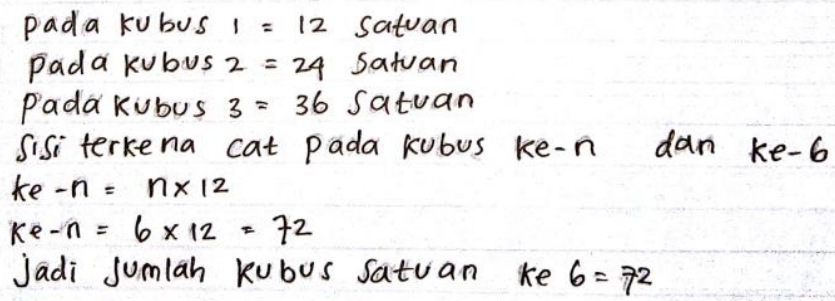

Gambar 18. Jawaban soal nomor 6 SA1

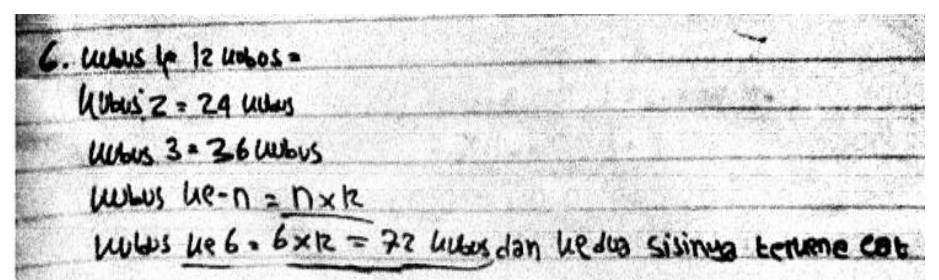

Gambar 19. Jawaban soal nomor 6 SK1

Sesuai dengan yang dapat dilihat pada Gambar 17, siswa visual kurang mampu menemukan pola atau sifat dari gejala matematis untuk membuat generalisasi, karena siswa visual hanya mampu menemukan selisih dari setiap susunan kubus yang kedua sisinya terkena cat. Namun, siswa visual tidak mampu membuat generalisasi atau menemukan rumusan dari pernyataan teratur untuk digunakan pada kondisi lain yang masih bersangkutan. Sehingga, siswa visual bisa menjawab jumlah satuan kubus yang kedua sisinya terkena cat pada kubus ke-6 dengan cara manual berdasarkan selisih yang telah diketahui, karena siswa visual tidak mampu menemukan $12 \times n$ sebagai generalisasi dari jumlah satuan kubus pada susunan kubus yang kedua sisinya terkena cat tersebut. 
Sesuai dengan yang dapat dilihat pada Gambar 18, siswa auditori mampu menemukan pola atau sifat dari gejala matematis untuk membuat generalisasi, karena siswa auditori mampu menemukan suatu susunan atau rumusan dari pernyataan teratur sehingga dapat digunakan pada kondisi lain yang masih bersangkutan. Siswa auditori mampu menemukan selisih jumlah satuan kubus yang terkena cat pada setiap susunan kubusnya, kemudian dari selisih tersebut siswa auditori mampu menemukan rumusan dari pernyataan teratur yaitu $12 \times n$. Setelah itu, dari rumusan tersebut digunakan pada kondisi lain yaitu menemukan jumlah satuan kubus yamg kedua sisinya terkena cat pada susunan kubus ke-6.

Sesuai dengan yang dapat dilihat pada Gambar 19, siswa kinestetik mampu menemukan pola atau sifat dari gejala matematis untuk membuat generalisasi, karena siswa kinestetik mampu menemukan suatu susunan atau rumusan dari pernyataan teratur sehingga dapat digunakan pada kondisi lain yang masih bersangkutan. Siswa kinestetik mampu menemukan kelipatan jumlah satuan kubus yang terkena cat pada setiap susunan kubusnya, kemudian dari kelipatan setiap susunan kubus tersebut siswa kinestetik mampu membuat generalisasi yaitu $12 \times n$. Untuk menemukan jumlah satuan kubus yang kedua sisinya terkena cat pada susunan kubus ke-6, siswa kinestetik menggunakan generalisasi yang telah dibuat karena kubus ke-6 merupakan kondisi lain yang masih bersangkutan dengan $12 \times \mathrm{n}$.

\section{KESIMPULAN}

Berdasarkan hasil penelitian dan pembahasan yang telah dikemukakan, maka dapat diambil kesimpulan bahwa siswa dengan gaya belajar visual memiliki kemampuan penalaran matematis yang baik pada indikator mengajukkan dugaan dan menarik kesimpulan dari pernyataan dengan baik. Namun, lemah pada indikator melakukan manipulasi matematika, menyusun bukti, memeriksa kesahihan argumen, dan membuat generalisasi. Siswa dengan gaya belajar auditori memiliki kemampuan penalaran matematis yang baik pada indikator menarik kesimpulan dari pernyataan, memeriksa kesahihan suatu argumen, dan menemukan pola atau sifat dari gejala matematis untuk membuat generalisasi. Namun, lemah pada indikator mengajukan dugaan, melakukan manipulasi matematika, dan menyusun bukti. Siswa dengan gaya belajar kinestetik memiliki kemampuan penalaran matematis yang baik pada indikator melakukan manipulasi matematika, menarik kesimpulan dari pernyataan, dan menemukan pola atau sifat dari gejala matematis untuk membuat generalisasi. Namun, lemah pada indikator mengajukan dugaan, menyusun bukti, dan memeriksa kesahihan suatu argumen. Siswa dengan gaya belajar visual, auditori, maupun kinestetik memiliki kemampuan penalaran yang baik dalam menarik kesimpulan dari pernyataan dengan baik. Sebaliknya, siswa dengan gaya belajar visual, auditori, maupun kinestetik memiliki kelemahan dalam menyusun bukti.

\section{REKOMENDASI}

Penelitian ini dapat menambah referensi bagi penelitian lanjutan yang terkait kemampuan penalaran matematis dan gaya belajar siswa. Pengetahuan tentang gaya belajar siswa dapat membantu siswa untuk mengembangkan cara belajarnya agar lebih optimal dalam menerima, menyerap, dan mengolah informasi atau materi pelajaran. Pengetahuan tentang gaya belajar siswa juga dapat guru dalam merancang pembelajaran yang tepat agar dapat memfasilitasi semua semua siswa dari berbagai gaya belajar yang berbeda. Selain itu, peneliti merekomendasikan kepada peneliti selanjutnya yang ingin menggunakan variabel penelitian yang sama untuk memberikan perlakuan berupa model pembelajaran dan menggunakan golongan gaya belajar yang lebih luas, sehingga dapat menganalisis lebih dalam mengenai kemampuan penalaran matematis siswa pada setiap golongan gaya belajarnya. 


\section{UCAPAN TERIMAKASIH}

Penulis mengucapkan terimakasih kepada Ibu Dr. Heni Pujiastuti, M.Pd dan Bapak Dr. Sukirwan, M.Pd selaku dosen pembimbing yang selalu sabar membimbing penulis dengan berbagai masukan, ide, saran yang bermanfaat, dan motivasi sehingga penelitian ini dapat berjalan dan terselesaikan dengan baik.

\section{DAFTAR PUSTAKA}

Agustina, L., Roesdiana, L., \& Imami, A. I. (2018). Implementasi model brain-based learning dalam meningkatkan kemampuan penalaran matematis siswa sma. Prosiding Sesiomadika, 1(1a), 410-424.

Asnawati, S. (2016). Penggunaan teknik murder pendekatan metakognitif untuk meningkatkan penalaran matematis mahasiswa pendidikan matematika pada mata kuliah geometri analitik. Teorema: Teori dan Riset matematika, 1(1).

Dani, S., Pujiastuti, H., \& Sudiana, R. (2017). Pendekatan realistic mathematics education untuk meningkatkan kemampuan generalisasi matematis siswa. Jurnal Penelitian dan Pembelajaran Matematika, 10(2), 182-193.

DePorter, \& Hernacky. (2013). Quantum learning membiasakan belajar nyaman dan menyenangkan. Kaifa.

Fadillah, A. (2016). Pembelajaran matematika dengan model core melalui pendekatan keterampilan metakognitif terhadap kemampuan penalaran matematis siswa smp. Jurnal Prima, 5(2), 1524.

Fajriyah, L., \& Zanthy, L. S. (2019). Penerapan pendekatan kontekstual terhadap kemampuan penalaran matematis siswa smp. Jounal on Education, 01(03), 211-216.

Farida, A. R., Caswita, \& Gunawibowo, P. (2018). Pengaruh model problem based learning terhadap kemampuan penalaran matematis siswa. Jurnal Pendidikan Matematika Unila, 6(6), 644654.

Hanifah, A. N., Sa'adah, N., \& Sasongko, A. D. (2019). Hubungan kemampuan penalaran matematis dan motivasi belajar siswa smk melalui model pembelajaran hypnoteaching. Teorema: Teori dan Riset matematika, 4(2), 121-130.

Haryono, A., \& Tanujaya, B. (2018). Profil kemampuan penalaran induktif matematika mahasiswa pendidikan matematika unipa ditinjau dari gaya belajar. Journal of Honai Math, 1(2), 127138.

Jaenudin, J., Nindiasari, H., \& Pamungkas, A. S. (2017). Analisis kemampuan berpikir reflektif matematis siswa ditinjau dari gaya belajar. Prima: Jurnal Pendidikan Matematika, 1(1), 6982.

Karim, A. (2014). Pengaruh gaya belajar dan sikap siswa pada pelajaran matematika terhadap kemampuan berpikir kritis matematika. Jurnal Formatif, 4(3), 188-195.

Kemdikbud. (2013). Standar Isi Pendidikan Dasar dan Menengah. Kemdikbud. 
Lestari, R. M., \& Prahmana, R. C. I. (2017). Model guided inquiry, student teams achievement division, dan kemampuan penalaran matematis siswa. Beta Jurnal Tadris Matematika, 10(2), 153-165.

Mikrayanti, M. (2016). Meningkatkan kemampuan penalaran matematis melalui pembelajaran berbasis masalah. Suska Journal of Mathematics Education, 2(2), 97-102.

NCTM. (2000). Principle and Standards for School Mathematics. NCTM.

Ridwan, M. (2017). Profil kemampuan penalaran matematis siswa ditinjau dari gaya belajar. KALAMATIKA Jurnal Pendidikan Matematika, 2(2), 193-206.

Sugiyono. (2010). Metode Penelitian Pendidikan. Alfabeta.

Sumarmo, U. (2013). Kumpulan makalah: Berpikir dan disposisi matematik serta pembelajarannya. Jurusan Pendidikan Matematika, FMIPA UPI.

Sumartini, T. S. (2015). Peningkatan kemampuan penalaran matematis siswa melalui pembelajaran berbasis masalah. Jurnal Pendidikan Matematika, 5(1), 1-10.

Utami, M. G., \& Meliasari. (2019). Analisis kemampuan penalaran matematika siswa ditinjau dari gaya belajar. Prosiding DPNPM, 5(1), 125-132. 